\title{
THERMO TECHNICAL MEASUREMENTS IN VIEW OF ESTABLISHING THE CONCENTRATION OF POLLUTANTS RELEASED INTO THE ATMOSPHERE
}

\author{
Lorand Toth ${ }^{1}$, Daniel Pupăzan ${ }^{1}$, Călămar Angelica ${ }^{1}$, Kovacs Marius $^{1}$
}

1 National Institute for Research and Development in Mine Safety and Protection to Explosion - INSEMEX, 32-34 G-ral Vasile Milea street, Petrosani, Romania

\begin{abstract}
One of the most important environmental problems in Romania is the air pollution, which is an extremely complex phenomenon.

Emissions from large industrial facilities represent a considerable share of total emissions of key atmospheric pollutants with significant environmental effects. Limiting emissions of pollutants released into the atmosphere are intended to protect the environment and biosystems as a whole against air pollution from anthropogenic activities.

The holders of stationary installations are required to systematically monitor emission levels and ensure their classification within the limits imposed by law.

In this sense, the present paper deals with determining the concentration of combustion gases (CO, NOx, SO2) emissions from large combustion installation which operate on solid fuel, process conditions resulting from waste gases and the calculation of the mass flow to identify the level of pollution in the studied area
\end{abstract}

Keywords: level of pollution, emissions, normalization, measurements program

\section{INTRODUCTION}

Development of human society creates an anthropogenic and technogenic impact on air quality. On a planetary scale, elimination or accumulation in the atmosphere of certain products, lead to irretrievable consequences on the planet's natural balance. Emissions from large industrial facilities are a significant part of the total emissions of key air pollutants environmental effects. Power plants are designed as basic power for the National Power System

The main parts of a plant are:

- Household fuel (solid) - to supply energy blocks;:

- Household liquid fuel tanks fitted with oil under / overground;

- Ash and slag deposits from the combustion of fuels;

- The boiler and related facilities;

- Steam turbines and related facilities;

- Energy blocks - containing electrical installations;

- Household electrical wiring and automation;

- Installations for the retention, disposal and dispersion of pollutants in the environment evidenced by electro-filters for retaining dust and various gas cleaning systems of combustion.

Large combustion plant operators are required under Law no. 278/2013 to monitor the emissions of sulfur dioxide and nitrogen oxides. Evaluation of gaseous pollutants in the large combustion plants is carried out in accordance with the technical requirements established by Order No. MAPPM. 462/1993, which governing the 
methodology for determination of emissions of air pollutants produced by stationary sources.

\section{EMISSIONS ARISING FROM BURNING}

Pollutants resulting from large combustion plants considered in the protection of the atmosphere (by Order 462/1993) are: sulfur dioxide $\left(\mathrm{SO}_{2}\right)$, nitrogen dioxide $\left(\mathrm{NO}_{2}\right)$, nitrogen oxides $\left(\mathrm{NO}_{\mathrm{x}}\right)$, carbon monoxide $(\mathrm{CO})$. and particulate matter $\left(\mathrm{PM}_{10}\right.$ and $\mathrm{PM}$ 2.5).

Effects of pollutants listed below are presented further.

Sulphur dioxide $\left(\mathrm{SO}_{2}\right)$ - a colorless, bitter, non-flammable, with a pungent odor that irritates the eyes and respiratory system.

The effects on health are based on the concentration and exposure time.

Exposure to a high concentration of sulfur dioxide in a short period of time, can cause serious breathing difficulties. Are particularly affected people with asthma, children, the elderly and people with chronic respiratory diseases. Exposure to reduced concentrations of sulfur dioxide in the long term can lead to infection of the respiratory tract.

Nitrogen oxides $\left(\mathrm{NO}_{\mathbf{x}}\right)$ - are a group of highly reactive gases which contain nitrogen and oxygen in varying amounts. Most of the nitrogen oxides are colorless and odorless gas. It is known to be very toxic gas both to humans and animals (the degree of toxicity dioxide is four times higher than that of nitrogen monoxide). Exposure to high levels could be fatal, and at low levels affects the lung tissue.

Population exposed to such pollutants can have breathing difficulties, respiratory irritation, lung dysfunction. Long-term exposure to a low concentration can destroy lung tissue resulting in emphysema. The people most affected by exposure to this pollutant are children.

Carbon monoxide (CO) - is a colorless, odorless, tasteless gas. It is a toxic gas in high concentrations is lethal (at concentrations of about $100 \mathrm{mg} / \mathrm{m}^{3}$ ) by reducing the oxygen carrying capacity of blood, with consequences on the cardiovascular system Respirators system. At relatively low concentrations of the central nervous system, reduce heart rate, thus decreasing blood volume in the body distribution, reduced visual acuity and physical ability, exposure for a short period can cause severe fatigue may cause shortness of breath and pain in the chest those diseases cardiovascular causes irritability, headache, tachypnea, lack of coordination, nausea, dizziness, confusion, reduced ability to concentrate.

Segment of the population most affected by exposure to carbon monoxide is children, the elderly, people with respiratory and cardiovascular diseases, anemic people and smokers.

Particulate matter $\left(\mathbf{P M}_{10}\right.$ and $\left.\mathbf{P M}_{2,5}\right)$ - is a complex mixture of small particles and aerosols.

Particle size is directly related to the potential to cause effects. An important issue is the particle diameter less than 10 micrometers, passing through the nose and throat and enters the pulmonary alveoli causing inflammation and poisoning. Are particularly affected people with cardiovascular and respiratory diseases, children, the elderly and asthmatics.

Children older than 15 years inhale more air, and therefore more pollutants. They breathe faster than adults and tend to breathe more on his mouth, practically bypassing natural filter and nose are especially vulnerable because their lungs are not developed and developing lung tissue is more sensitive. 


\section{GENERAL REQUIREMENTS FOR MONITORING DISCONTINUOUS LARGE COMBUSTION PLANTS}

Discontinuous measurements of emissions have as result emission behavior of plant, punctual and limited in time.

Monitoring by discontinuous measurements of $\mathrm{SO}_{2}, \mathrm{NO}_{x}$ and dust is made in all cases where continuous monitoring is not requiredln the event of non continuous measurements, the competent authority for environmental protection have performed discontinuous measurements or other appropriate determination procedures, verified and approved it, leading in evaluation of the quantities of emissions of sulfur dioxide, nitrogen oxides and dust, with a frequency at least every 6 months. Discontinuous measurements shall be performed in the following cases:

- For large combustion plants whose life is more than 10,000 hours;

- Emissions of sulfur dioxide and dust emissions from the combustion of natural gas in boilers or gas turbines;

- Sulfur dioxide emissions from gas turbines or boilers which burn oil with known sulfur content, if they do not have desulphurisation equipment;

- Sulfur dioxide emissions from boilers using biomass combustion process, provided that the holder activity to justify technically that emissions of sulfur dioxide can be in no case greater than the limit emission set.

Measuring pollutants $\mathrm{SO}_{2}, \mathrm{NO}_{x}$ and particulate involve in Annex 2 of GD. 541/2003, simultaneously measure the relevant process parameters: temperature, pressure, oxygen content of the flue gas water vapor as required by the methods of measurement used.

In order to draw some conclusions on the emissions of installations operating continuously applying measurement procedures in a limited amount of time, measurements must be made in such a way that the results are representative of the emission behavior of the system. Therefore the planning of this activity is an extremely important factor.

The purpose of the current surveillance installations that do not require continuous monitoring to establish a monitoring program to be approved batch by the competent authority for environmental protection environment and is included in the integrated environmental authorization. In determining the measurement program are taken into account technological features of the system.

Measurement program must cover all phases of operation of the plant. Measurements should be relevant for all situations - known operating conditions (operating cycles, fuel switching, changes which affect emissions etc.)

\section{PRESENTATION OF THE METHOD FOR DETERMINING GASEOUS POLLUTANTS WITH TESTO 350XL EQUIPMENT}

Determining method for gaseous components from industrial emissions is the direct method with Multigas unit.

The test method is to determine the concentration of gas samples taken from emissions from stationary sources (industrial chimneys, pipes) using Testo 350XL equipment.

Multigas analyzer TESTO $350 \mathrm{~L}$ is composed of the sampling probe unit for analyzing and control unit Figure 1 ( $A, B, C)$. Samples are taken with internal pump unit and on the route the suction gas is cooled to $4-8^{\circ} \mathrm{C}$, water vapor is condensed directly results in the lowest moisture absorption by $\mathrm{NO}_{2}$ and $\mathrm{SO}_{2}$. The condensate is pumped at regular intervals Desiccator body installed on equipment. 
Dry gas is passed through filters that are designed to retain the suspension. The filters also have function to retain water vapor. If filters are waterlogged, their pores closed and protects the pump and internal sensors. A very small proportion of the gas passes through the sensor membrane, where the concentration of the gas is converted into electrical signals, excess gas is removed.

For gaseous effluent, sampling is used a stainless steel metal probe provided inside with a thermocouple to determine the temperature of the effluent.

Analysis and control unit is composed of:

- Sampling pump - the role of extracting a sample from inside the chimney / pipe through sampling system (probe);

- Primary filter to retain particles with a diameter less than 10 micrometres (mounted at the tip of the sample probe), which will clean up after each determination to avoid condensation reactions between gases measured which would lead to erroneous results;

- Secondary filter to remove particulates in order to protect the pump (analyzer). It is included in the sampling line as well. The use of this filter for retaining the particles with a diameter greater than $1 \mu \mathrm{m}$.

- Water vapor elimiarea device operating on the principle of condensation / cooling water vapor;

- Measuring cells, which are intended to produce an electro-optical or chemical response corresponding to the gas concentration.

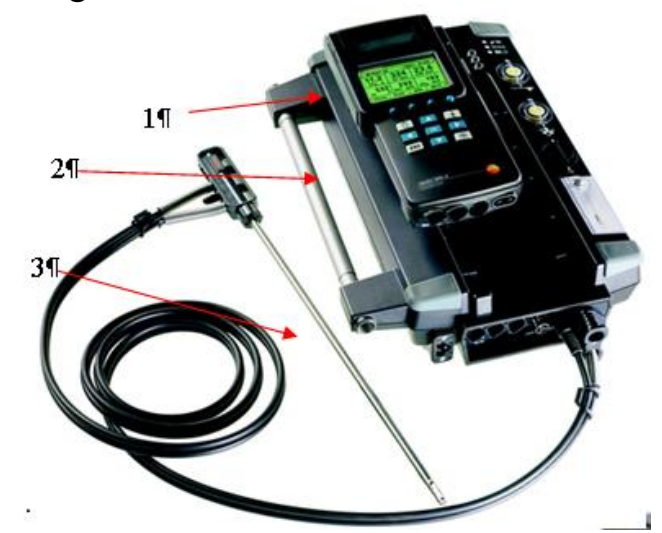

A. Control unit

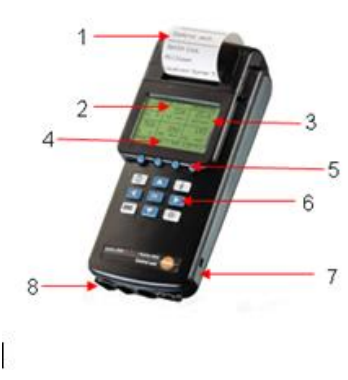

B. Logger

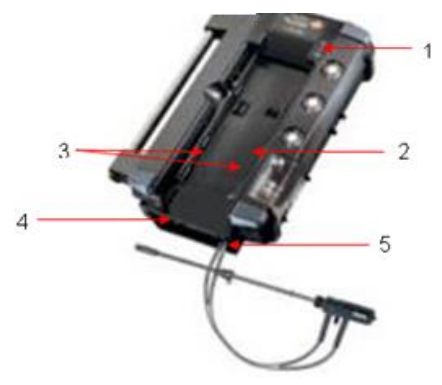

C. Sampling probe

Fig 1 - Multigas analyzer TESTO 350 XL

A.

1 Control unit
B.

1 Printer c.

1 Status led 


$\begin{array}{lll}2 \text { Logger } & 2 \text { Toolbari } & 2 \text { Tool holder } \\ 3 \text { Sampling probe } & 3 \text { Display } & 3 \text { Direct contacts } \\ & 4 \text { Toolbar functions } & 4 \text { Connections } \\ & 5 \text { Function key } & 5 \text { Sampling probe } \\ & 6 \text { Toggle Keys } & \\ 7 \text { Network Connection } & \\ 8 \text { PC interface } & \end{array}$

\section{PROCESS CONDITIONS FROM WHICH ARE RESULTING WASTE GASES}

Steam generators with power steam turbines are vital parts in large combustion plants that produce electricity.

To know the operating conditions of the steam generator during thermo technical measurement should be noted that this is a heat exchanger characterized by certain operating parameters .

Functional parameters of a steam generator are given for pressure, temperature and flow of feedwater and steam under certain conditions.

- operating pressure - defined as the vapor pressure is determined based on the output of the superheater;

- nominal temperature of the steam - is the maximum steam temperature at the outlet of the main valve to the pressure and the flow rate in continuous operation, and corresponds to the temperature of superheated steam from the superheater outlet base;

- supply water temperature - the temperature of the water supply inlet steam generator; - the normal flow of steam - steam flow is properly functioning steam generator to the optimum thermal efficiency, which corresponds to about $80 \%$ of the nominal flow of steam;

The data presented below have resulted from a campaign measurement during February -May 2016, at a large facility that works on burning fossil fuel (lignite).

In Table no. 1 are shown the operating conditions of the steam generator during performed thermo technical measurement:

Table no. 1 - Operating conditions of the steam generator

\begin{tabular}{|l|l|c|c|}
\hline $\begin{array}{l}\text { Crt. } \\
\text { no. }\end{array}$ & \multicolumn{1}{|c|}{ Functional parameters } & M.U. & Value \\
\hline 1 & The flow of superheated steam & t/h & 250 \\
\hline 2 & The pressure of the superheated steam & bar & 135 \\
\hline 3 & Overheating temperature & ${ }^{\circ} \mathrm{C}$ & 527 \\
\hline 4 & The flow rate of feed & $\mathrm{t} / \mathrm{h}$ & 256 \\
\hline 5 & The temperature of the supply water & ${ }^{\circ} \mathrm{C}$ & 230 \\
\hline 6 & Water supply pressure & $\mathrm{bar}$ & 195 \\
\hline 7 & Monthly consumption of coal & $\mathrm{t} / \mathrm{h}$ & 109,75 \\
\hline 8 & Calorific value of coal & $\mathrm{Kcal} / \mathrm{kg}$ & 1600 \\
\hline
\end{tabular}




\begin{tabular}{|l|l|c|c|}
\hline 9 & Total moisture of coal & $\%$ & 46,4 \\
\hline 10 & The ash content of the coal & $\%$ & 39,2 \\
\hline 11 & Hourly consumption of naphtha & $\mathrm{t} / \mathrm{h}$ & 0,417 \\
\hline 12 & Calorific value of naphtha & $\mathrm{Kcal} / \mathrm{kg}$ & 9733 \\
\hline 13 & The sulfur content of naphtha & $\%$ & 0,58 \\
\hline
\end{tabular}

\section{MASS FLOW CALCULATION}

The measured results are shown in the file generated by the application saved in the computer, which is expressed in $\mathrm{mg} / \mathrm{m}^{3}$ or \% vol depending on specific parameters. The final value is obtained by normalizing the outcome. Thus it relates to standard conditions of temperature, volume fraction of oxygen and moisture., shown in the Table no. 2 .

Table no.2 - Summary on concentrations normalized emissions

\begin{tabular}{|c|c|c|c|c|c|}
\hline $\begin{array}{l}\text { Crt. } \\
\text { no. }\end{array}$ & $\begin{array}{c}\text { Location / } \\
\text { Installation Name } \\
\text { /Technological flow }\end{array}$ & $\begin{array}{l}\text { Measuring } \\
\text { component }\end{array}$ & $\begin{array}{l}\text { Medium } \\
\text { value } \\
{\left[\mathrm{mg} / \mathrm{m}^{3} \mathrm{~N}\right]}\end{array}$ & $\begin{array}{c}\text { Value } \\
\text { maximum } \\
{\left[\mathrm{mg} / \mathrm{m}^{3} \mathrm{~N}\right]}\end{array}$ & $\begin{array}{l}\text { Observations } \\
\text { (Process } \\
\text { conditions from } \\
\text { which are } \\
\text { resulting waste } \\
\text { gases) } \\
\end{array}$ \\
\hline \multirow{5}{*}{1} & \multirow{5}{*}{$\begin{array}{c}\text { Chimney no. } 2 \text { upper } \\
\text { channel } \mathrm{K} 4,\end{array}$} & $\mathrm{CO}$ & 163,72 & 194,5 & \multirow{5}{*}{$\begin{array}{l}\mathrm{T}_{\text {environmental }}=8,14^{\circ} \mathrm{C} \\
\mathrm{T}_{\text {effluent }}=149,52{ }^{\circ} \mathrm{C} \\
\mathrm{P}_{\text {environmental }}=1004,1 \\
\text { mbar } \\
\mathrm{CO}_{2}=6,77 \% \mathrm{vol} \\
\mathrm{O}_{2}=13,81 \% \mathrm{vol} \\
\mathrm{v}=12,7 \mathrm{~m} / \mathrm{s} \\
\mathrm{Q}=439654,95 \mathrm{~m}^{3} / \mathrm{h} \\
\lambda=7,31\end{array}$} \\
\hline & & NO & 185,3 & 207,4 & \\
\hline & & $\mathrm{NO}_{2}$ & 4,78 & 12,7 & \\
\hline & & NOx & 190,20 & 206,1 & \\
\hline & & $\mathrm{SO}_{2}$ & 4313,8 & 4582,7 & \\
\hline \multirow{5}{*}{2} & \multirow{5}{*}{$\begin{array}{c}\text { Chimney no. } 2 \text { lower } \\
\text { channel K4, }\end{array}$} & $\mathrm{CO}$ & 179,45 & 209,3 & \multirow{5}{*}{$\begin{array}{l}\mathrm{T}_{\text {environmental }}=8,14^{\circ} \mathrm{C} \\
\mathrm{T}_{\text {effluent }}=147,31^{\circ} \mathrm{C} \\
\mathrm{P}_{\text {environmental }}=1004,3 \\
\mathrm{mbar} \\
\mathrm{CO}_{2}=6,39 \% \mathrm{vol} \\
\mathrm{O}_{2}=13,76 \% \mathrm{vol} \\
\mathrm{v}=12,4 \mathrm{~m} / \mathrm{s} \\
\mathrm{Q}=429269,40 \mathrm{~m}^{3} / \mathrm{h} \\
\lambda=6,82\end{array}$} \\
\hline & & $\mathrm{NO}$ & 203,34 & 228,7 & \\
\hline & & $\mathrm{NO}_{2}$ & 5,27 & 18,2 & \\
\hline & & NOx & 208,61 & 305,4 & \\
\hline & & $\mathrm{SO}_{2}$ & 4571,5 & 4679,5 & \\
\hline
\end{tabular}

The mass flow was determined by the product of the concentrations determined in the effluent and flow rate of the channel. Following the calculation and adjustment of units in the Table no. 3 are presented centralized the mass flow values obtained. 
Table no. 3 - mass flow rates calculated from measurements of emissions

\begin{tabular}{|l|c|c|c|}
\hline Channel K4 & $\begin{array}{c}\mathbf{C O}_{2} \text { Flow } \\
(\mathbf{t} / \mathbf{h})\end{array}$ & $\begin{array}{c}\mathbf{S O}_{2} \text { Flow } \\
(\mathbf{t} / \mathbf{h})\end{array}$ & $\begin{array}{c}\mathbf{N O}_{\mathbf{x}} \text { Flow } \\
(\mathbf{t} / \mathbf{h})\end{array}$ \\
\hline Upper & 12,8823 & 1,0074 & 0,07362 \\
\hline Lower & 13,7151 & 0,9812 & 0,07955 \\
\hline
\end{tabular}

\section{CONCLUSIONS}

Currently, the share of solid fuels used for electricity production is still large thermal power plants are a major source of environmental pollution.

Through the chimneys, power plants emit into the atmosphere continuously and consistently huge volume of flue gas containing gaseous pollutants and particulate concentrations.

Gas concentrations in the effluent was normalized in function of oxygen (6\%), temperature $(273,15 \mathrm{~K})$ and pressure $(1013 \mathrm{mbar})$ in accordance with law in force.

Measured concentrations exceed the upper channel emission limit values according to Law no. $278 / 2013$ for $\mathrm{SO}_{2} 3913.8 \mathrm{mg} / \mathrm{m}^{3} \mathrm{~N}$ and $\mathrm{NOx}$ by $90.2 \mathrm{mg} / \mathrm{m}^{3} \mathrm{~N}$.

Lower channel measured concentrations exceed the emission limit values according to Law no. $278 / 2013$ for $\mathrm{SO}_{2} 4171,5 \mathrm{mg} / \mathrm{m}^{3} \mathrm{~N}$ and NOx with $108,61 \mathrm{mg} / \mathrm{m}^{3} \mathrm{~N}$.

At the request of the environmental authorities for large combustion plants required mass flow and declaration in accordance with legislative requirements and environmental permits.

\section{REFERENCES}

1. Ciolea Daniela, Air depollution, Universitas Publishing House, Petrosani, 2012

2. Marinescu M., Ştefănescu D., Large Combustion Plants, Technical Publishing House, Bucharest, 1985

3. Toth L., Găman, G. A., Călămar A., ş.a. - The normalization of gaseous effluents pollutants from large combustion plants, ECO IST International Symposium, Serbia, 2015

4. ${ }^{*} *$ * PN 074502 26, Development of prevention and reduction of dust and gas concentrations in hazardous environments and / or toxicity of the power plants according to the best European practices in the field

$5 .{ }^{* *}{ }^{*} 2010 / 75 / C E$ Directive related to industrial emissions

6. * * * Law no. 278/2013 related to industrial emissions

7. * * *aw no. 104/2011 on ambient air quality

8. * * MAPPM Order No. 462/1993 Technical requirements on protection of the atmosphere 